The International Journal of

Interdisciplinary

Educational Studies

Making Formative Tests More Genuine 


\section{EDITOR}

Marcin Galent, Jagiellonian University, Poland

ACTING DIRECTOR OF PUBLISHING

Jeremy Boehme, Common Ground Research Networks, USA

\section{MANAGING EDITOR}

Megan Donnan, Common Ground Research Networks, USA

\section{ADVISORY BOARD}

The Interdisciplinary Social Sciences Research Network recognizes the contribution of many in the evolution of the Research Network. The principal role of the Advisory Board has been, and is, to drive the overall intellectual direction of the Research Network. A full list of members can be found at https://thesocialsciences.com/about/advisory-board.

\section{PEER REVIEW}

Articles published in The International Journal of Interdisciplinary Educational Studies are peer reviewed using a two-way anonymous peer review model. Reviewers are active participants of The Interdisciplinary Social Sciences Research Network or a thematically related Research Network. The publisher, editors, reviewers, and authors all agree upon the following standards of expected ethical behavior, which are based on the Committee on Publication Ethics (COPE) Core Practices. More information can be found at: https://thesocialsciences.com/journals/model.

\section{ARTICLE SUBMISSION}

The International Journal of Interdisciplinary Educational Studies publishes biannually (June, December). For more about the submission process, please visit https://thesocialsciences.com/journals/call-for-papers.

\section{THE INTERNATIONAL JOURNAL OF}

\section{INTERDISCIPLINARY EDUCATIONAL STUDIES}

https://thesocialsciences.com

ISSN: 2327-011X (Print)

ISSN: 2327-2570 (Online)

https://doi.org/10.18848/2327-011X/CGP (Journal)

First published by Common Ground Research Networks in 2020

University of Illinois Research Park

2001 South First Street, Suite 202

Champaign, IL 61820 USA

$\mathrm{Ph}:+1-217-328-0405$

https://cgnetworks.org

\section{The International Journal of Interdisciplinary}

Educational Studies is a peer-reviewed, scholarly journal.

\section{COPYRIGHT}

(C) 2020 (individual papers), the author(s)

(C) 2020 (selection and editorial matter),

Common Ground Research Networks

All rights reserved. Apart from fair dealing for the purposes of study, research, criticism, or review, as permitted under the applicable copyright legislation, no part of this work may be reproduced by any process without written permission from the publisher. For permissions and other inquiries, please contact cgscholar.com/cg_support.

\section{Crossref}

Common Ground Research Networks, a member of Crossref

\section{ABSTRACTING AND INDEXING}

For a full list of databases in which this journal is indexed, please visit https://thesocialsciences.com/journals/collection.

\section{RESEARCH NETWORK MEMBERSHIP}

Authors in The International Journal of Interdisciplinary Educational Studies are members of the Interdisciplinary Social Sciences Research Network or a thematically related Research Network. Members receive access to journal content. To find out more, visit https://thesocialsciences.com/about/become-a-member.

\section{SUBSCRIPTIONS}

The International Journal of Interdisciplinary Educational Studies is available in electronic and print formats. Subscribe to gain access to content from the current year and the entire backlist. Contact us at cgscholar.com/cg support.

\section{ORDERING}

Single articles and issues are available from the journal bookstore at https://cgscholar.com/bookstore.

\section{HYBRID OPEN ACCESS}

The International Journal of Interdisciplinary Educational Studies is Hybrid Open Access, meaning authors can choose to make their articles open access. This allows their work to reach an even wider audience, broadening the dissemination of their research. To find out more, please visit https://thesocialsciences.com/journals/hybrid-open-access.

\section{DISCLAIMER}

The authors, editors, and publisher will not accept any legal responsibility for any errors or omissions that may have been made in this publication. The publisher makes no warranty, express or implied, with respect to the material contained herein. 


\title{
Making Formative Tests More Genuine
}

\author{
Siti Mina Tamah, ${ }^{1}$ Widya Mandala Surabaya Catholic University, Indonesia
}

\begin{abstract}
In Indonesia, current face-to-face classroom based instruction has been packed with student grouping. When it comes to a formative test, learners are commonly expected to do quizzes or formative tests individually-similar to summative tests occurring in a four-wall classroom. This reveals that there is a distortion between the regular instructional practice and the test practice. The argument underlying this thought-provoking article is that it is essential for formative test administration to come closer to the paradigm implemented on a regular basis. A recent challenging design is on its way for teamwork assessment: group oriented, representative oriented, and structured discussion oriented. This small-scale study attempts to depict the implementation of the challenging design with regard to assessment-oriented formative tests and reports how they are perceived by students. The study reveals that the new design has received positive feedback.
\end{abstract}

Keywords: Formative Test, Group Work, Representativeness, Structured Discussion, Authentic Assessment

\section{Introduction}

$\mathrm{T}$ The Faculty of Teacher Training at the site university in Indonesia for this investigation strongly encourages faculty members to devote themselves not only to achieving the goals of the university but also to producing entrants to the teaching profession who will be highly proficient in a range of student assessment practices. To realize these aspirations, faculty members are required to engage in ongoing professional development for the purposes of remaining informed about new developments in teaching practice and of achieving personal professional growth. To be effective, this engagement must be intentional, ongoing, and systematic (Guskey 2000). It is in this context that the researcher decided to empirically explore an issue in student assessment that was identified to be in need of serious attention at at the site university, namely Widya Mandala Surabaya Catholic University, Indonesia (Tamah and Prijambodo 2014; Tamah 2017). The issue concerned a clearly obvious gap between how teaching was implemented and how learning was assessed.

In the Indonesian context, especially at the site university, face-to-face classroom instruction still dominates though online instruction utilizing a learning management system is also encouraged. Thus it becomes the norm for teachers to be in class with the students and to be engaged together for classroom instruction. The requirement to attend classes in person is still a major concern. This is proved by the regulation that at least 75 percent of class attendance is obligatory for students to take the final semester test of the respective class. A similar regulation is applied to the teachers who must fulfill the regular class attendance for at least fourteen meetings in a semester.

Teaching at the site university typically involves forming students into small learning groups, where they work on various tasks as assigned by the relevant faculty members (Tamah 2017; Tamah and Wirjawan 2018; Xethakis 2016). This small-group approach to learning has multiple advantages. Students feel more involved and engaged, which is consistent with findings reported internationally (McKeachie 1994). Assigning specific roles to individual students working in the context of a small learning group assists low-achieving students, in particular, because it prompts them to become less passive and more involved (Tamah 2011). In short, learning within small groups is commonplace across the site university, and its impact is widely accepted to be extremely beneficial.

\footnotetext{
${ }^{1}$ Corresponding Author: Siti Tamah, Kalijudan 37 Surabaya, English Department, Widya Mandala Surabaya Catholic University, Surabaya, East Java, 60114, Indonesia. email: mina@ukwms.ac.id
} 
When it comes to assessing student learning, however, a summative paradigm prevails. The institution is rigorous in seeking to ensure that student learning is assessed against the published learning aims for each of the units of study in a degree program. Within individual units of study, there is little use made of formative student assessment. There appears, therefore, to be a mismatch between the collaborative forms of teaching and a culture which supports a summative approach to the confirmation of learning. A survey of faculty members at the site university indicated that about three-quarters of them were happy with this situation, preferring to employ summative assessment methods to test student learning, even though the context within which the learning had taken place was collaborative in nature (Tamah and Wirjawan 2018). This finding resonated with a finding reported earlier by Tamah and Prijambodo (2014).

This situation was considered by the researcher to be problematic. If the context for learning is collaborative, then a more authentic approach to the testing of learning would be one that is also collaborative. In other words, there should be a culture of support for formative approaches to the assessment of learning at the site institution. It is in this context that the present investigation was designed and implemented.

\section{Formative Assessment}

Formative assessment is most simply explained as "assessment for learning," that is, the focus of the assessment task is to enable the students to engage in a learning experience in which they are able to self-monitor their progress with a view to achieving a certain learning standard. The assessment instruments employed are intended to inform the student about progress and to take more personal responsibility for making progress with learning. It is the kind of assessment that prompts the student to obtain feedback from a teacher or from peers on progress being made with respect to meeting an academic goal. It is also, as Torrance and Pryor (1998) have identified, an approach to assessment in which there is a focus on regulating student behavior for the purposes of guiding students with respect to the attainment of future learning. Formative assessment is consistent with a more learner-centered teaching paradigm. It has been addressed in the relevant literature from a variety of conceptual perspectives, including holistic assessment (Jacobs and Renandya 2016) and alternative assessment (Brown and Abeywickrama 2010; Warsono and Hariyanto 2012). Research about formative assessment highlights the pedagogical principles upon which the practice is based (see, for example, Wiliam, Lee, Harrison, and Black 2004).

Formative assessment stands in contrast to summative assessment, which may be described as "assessment of learning." In summative assessment, the aim is to judge performance in achieving a certain standard of performance with respect to an educational goal. A typical example is an end-of-semester examination in which grades achieved are intended to provide a final determination of the quality of learning achieved.

The research literature on formative assessment has pointed to its merits as a learning tool. This literature has also identified tensions that may exist between formative and summative assessment. According to the Center for Educational Research and Innovation (CERI):

Teachers using formative assessment approaches guide students toward development of their own "learning to learn" skills-skills that are increasingly necessary as knowledge is quickly outdated in the information society. $(2018,1-2)$

The Center has also identified that:

While teachers often express ambivalence or resistance to external summative tests, there is nothing inherent in summative assessment to prevent teachers from using formative methods. Indeed, summative results can be used formatively. $(2018,3)$ 
Some studies of formative tests have centered on the issue of the effect of formative test frequency on summative tests (Bangert-Drowns, Kulik, and Kulik 1991; McDaniel, Widman, and Anderson 2012; Moyosore 2015; Wambuguh and Yonn-Brown 2013). Primarily the studies have been concerned with the issue of whether having more quizzes is influential for the final achievement of a class program.

Jacobs and Renandya (2016) provide a practical example of formative assessment, using a 3-2-1 technique. The technique is implemented as follows:

3. At some point in a lesson, pairs of students write a total of three points they have learnt so far - the three statements pointed out are intended for learning consolidation.

2. Each member in the pair asks two questions: one is related to the materials not mastered yet, and the other one is future-oriented to get new additional knowledge. The two-question posing is intended to show that learning is never complete.

1. Each member thinks of one way to assist understanding of why they learn what they learn.

Brown (2016), writing an assessment issue in an edited book, highlights twelve assessment options currently available for language teachers: true-false, multiple-choice, matching items (classified as receptive-response set), fill-in and short-answer items, performance assessment (classified as productive-response set), portfolio, conferences, self/peer assessment (classified as personal-response set), continuous, differentiated, and dynamic assessment (classified as individualized-response set). He further examines the pedagogical implications of those twelve assessment types based on the content, the logistical issue, the scoring, and the communicative characteristics.

Tamah and Wirjawan (2019) argue for authentic assessment to include students' engagement and collaboration. They further point out:

This indicates that even when doing the test, the process of learning and collaborating should take place-revealing further the encouragement for the diminishing of individual oriented formative test or a conventional formative test....It is even indicative that the cooperation should exist appropriately during the test-group learning still occurs in formative testing. $(2019,69-70)$

Reviews of the literature on formative assessment previously indicate that none has touched upon the concern on the gap found between group-oriented teaching and individual-oriented assessment. Neither has attention been given to the issue on how to make assessment activities more closely aligned with students' experiences on a daily basis. This paper is intended to respond to this particular issue.

\section{A New Design Introduced}

Referring to a research report (Tamah and Prijambodo 2014) and explicit ideas of very structured assessment (Tamah 2017), a three-argument assessment design with regard to assessment-oriented formative testing is highlighted. The first argument orientates the change from individual assessment into group assessment. The second orientates the change from individual assessment to representative assessment —one implementing that not all members in the group take the quiz or the formative test (only two of three or four members are chosen randomly to be quiz takers representing the group). The third orientates the change from individual assessment to representative assessment with structured discussion. The voice of a group of learners joining an English class, where the implementation of the assessment design is carried out, will be reported. 
The first argument - the change from individual assessment into group assessment-is to narrow the gap that happens between the regular instructional teaching and testing. As mentioned earlier, it is inevitable to match these two bodies: the day-to-day practice which is group oriented and the test. When teaching is group-oriented, the test should also be group oriented. It should not be individual oriented.

The second argument - the change from individual assessment into representativenessoriented assessment - shall indicate the reinforcement of role interdependence during the formative test administration. Two roles must be decided: quiz takers (test takers) and non-quiz takers (non-test takers). The students becoming the quiz takers work individually. Meanwhile the ones becoming the non-quiz takers work together; they are assigned to be ready to assist the quiz takers during the discussion phase. This particular argument is captured more with the following three-phase illustration (see Figure 1). The first phase-100 percent of quiz time-is for the quiz takers to work on their own; meanwhile, the non-quiz takers are encouraged to work together to help each other so that each can assist the quiz takers. The second phase- 50 percent of quiz time - is the discussion phase which is, as its name suggests, the time for discussion between the quiz taker and the non-quiz taker who are paired. The third phaseabout 20 percent of quiz time - is similar to the first phase. With regards to time allotment of this three-phase design for formative assessment, it is suggested that teachers follow 100 percent-50 percent-20 percent formula (A 30 minute quiz time typically has the time allotment as follows: 30 minutes, 15 minutes, and 5 or 6 minutes for Steps 1-3, respectively). The quiz takers are responsible for tidying their work and deciding which answers to keep. Individual accountability, one essential component of cooperative learning, is upheld here. The positive interdependence is further strengthened especially when the average scores of the quiz takers are taken for each member in the group.

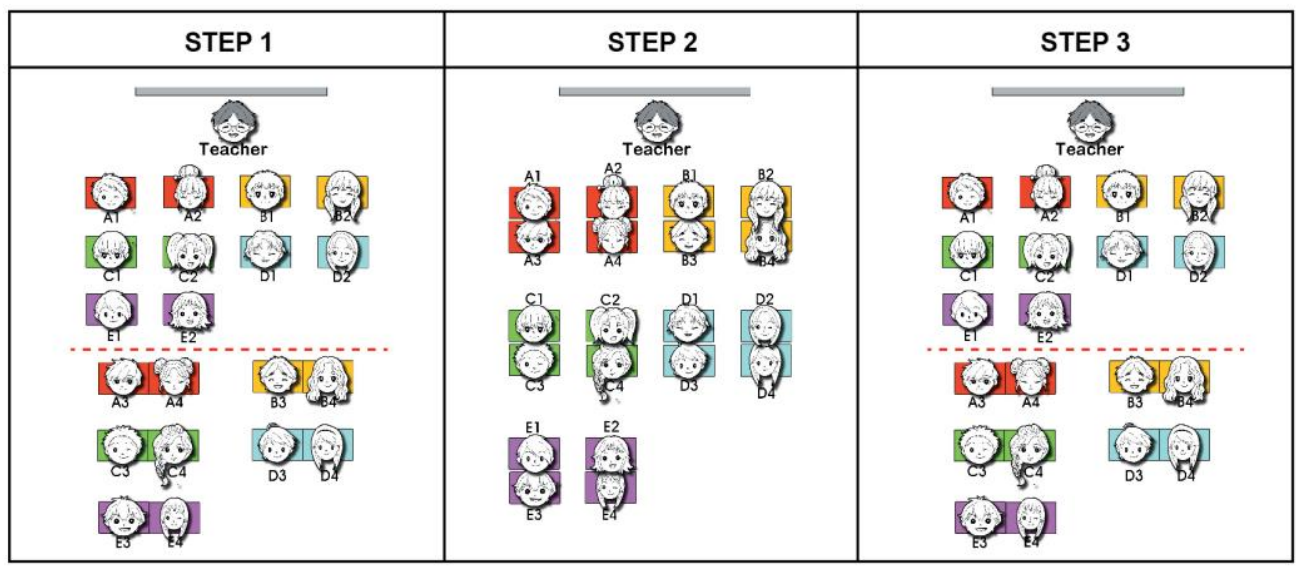

Figure 1 The Three-step More Genuine Formative Test Design Source: Tamah 2017

The third argument - the change from individual assessment into representative assessment with structured discussion-follows the perspective that meaning is constructed through collaborative or dialogical activity. As argued by Mercer (1995), new knowledge and understanding comes into existence when it is communicated-constructed and negotiated through talk. It is also through interaction that knowledge is constructed (Wenger 1998). Lantolf's (2000) sociocultural theory lies behind this third argument. Structured discussion provided in this innovation means interaction existing, and as a result learning is aided in the long run.

Figure 1 illustrates the three steps implemented on the quiz day. In the first step, the quiz takers chosen were in their area in the front space of the classroom; the non-quiz takers were at 
the back (this front-back formation can be changed into left-right formation). The quiz takers did the test individually; the quiz takers did the test in pairs - discussion was allowed. In the second step, the quiz takers and non-quiz takers in each group were paired. The quiz takers were assisted by the non-quiz takers. The paired discussion was expected to be process-oriented when the pairs interacted to discuss certain quiz items. In the third step, the quiz takers were left by the non-quiz takers (similar to Step 1). The completed quiz by the quiz takers were scored and averaged. It would be one score obtained from the quiz takers' implying that each group member got the average score.

\section{Method}

This small-scale exploratory study is descriptive in nature. It attempts to depict the implementation of a current newly introduced design with regard to assessment-oriented formative test and reports how they are perceived by students. In the even semester of 2016/2017 academic year, the quiz design was implemented in "English for Food Technology" course, a two-credit compulsory English course appearing in the syllabus of an Agriculture Faculty at the site university. There were fifty-five students registered in the class. They were freshmen aged 19-20 years old. They were enrolled in a class out of three parallel English for Specific Purposes classes formed. The predetermined course objective was to understand English texts on Food Technology.

On the very first meeting of this reading-oriented class, the students did an individual small pre-test from which the scores were taken. The scores were used as the basis for small group formation. The small groups formed were heterogeneous with regards to academic ability.

In regular class sessions, group work was mostly implemented. During that semester program, two formative tests, commonly named quizzes at the university, were administered. The first quiz was held in the middle of the first half of the semester. The second was held in the middle of the second half of the semester. After the first quiz and also after the second quiz, the students were asked to reveal their perception on the design. A small piece of paper was distributed for each student to respond to the statements displayed on the screen. Using LCD and laptop facilities in the class, each student rated statements from which their perception of the design could be identified. No name was required. The responses were reported on a 4-point Likert scale: 1 for "strongly disagree," 2 "disagree," 3 "agree," and 4 "strongly agree."

All fifty-five students were present on the quiz day. At the beginning of the quiz day, the researcher again explained that the quiz would be group oriented. The first data collection was carried out right after the first quiz was over. However, on the day for the second data collection, only thirty-six students were present. It was the last session of the semester program (and so the number of students was different when the first perception and second perception were calculated).

\section{Findings}

With regard to the perception on whether students think the nature of group work is represented in the implementation, the findings are indicated in the following table: 
Table 1 Group Work and Learning Manifestation

\begin{tabular}{|c|c|c|c|c|c|c|c|c|c|c|c|c|}
\hline & \multicolumn{6}{|c|}{ Sustained Nature of Group Work } & \multicolumn{6}{|c|}{ Manifestation of Learning } \\
\hline & \multicolumn{3}{|c|}{$\begin{array}{c}\text { First } \\
\text { Perception }\end{array}$} & \multicolumn{3}{|c|}{$\begin{array}{c}\text { Second } \\
\text { Perception }\end{array}$} & \multicolumn{3}{|c|}{$\begin{array}{c}\text { First } \\
\text { Perception }\end{array}$} & \multicolumn{3}{|c|}{$\begin{array}{c}\text { Second } \\
\text { Perception }\end{array}$} \\
\hline & 0 & \multirow{2}{*}{ No } & \multirow{2}{*}{$\begin{array}{c}5 \\
(9.1 \%)\end{array}$} & 0 & \multirow{2}{*}{ No } & \multirow{2}{*}{$\begin{array}{c}2 \\
(5.6 \%)\end{array}$} & 4 & \multirow{2}{*}{ No } & \multirow{2}{*}{$\begin{array}{c}7 \\
(12.7 \%)\end{array}$} & 0 & \multirow{2}{*}{ No } & \multirow{2}{*}{$\begin{array}{c}1 \\
(2.8 \%)\end{array}$} \\
\hline$D$ & 5 & & & 2 & & & 3 & & & 1 & & \\
\hline$A$ & 44 & \multirow{2}{*}{ Yes } & \multirow{2}{*}{$\begin{array}{c}50 \\
(90.9 \%)\end{array}$} & 26 & \multirow{2}{*}{ Yes } & \multirow{2}{*}{$\begin{array}{c}34 \\
(94,4 \%)\end{array}$} & 42 & \multirow{2}{*}{ Yes } & \multirow{2}{*}{$\begin{array}{c}48 \\
(87.3 \%)\end{array}$} & 23 & \multirow{2}{*}{ Yes } & \multirow{2}{*}{$\begin{array}{c}35 \\
(97.2 \%)\end{array}$} \\
\hline$S A$ & 6 & & & 8 & & & 6 & & & 12 & & \\
\hline & 55 & & $\begin{array}{c}55 \\
(100 \%)\end{array}$ & 36 & & $\begin{array}{c}36 \\
(100 \%)\end{array}$ & 55 & & $\begin{array}{c}55 \\
(100 \%)\end{array}$ & 36 & & $\begin{array}{c}36 \\
(100 \%)\end{array}$ \\
\hline
\end{tabular}

Note: SD: Strongly Disagree; D: Disagree; A: Agree; SA: Strongly Agree

Source: Tamah 2020

The majority of the students (slightly above 90\%) agreed that the test did represent the nature of group work. The perception is even more positive as it reaches about 94 percent after they get the quiz two times or after the design is implemented twice. With regard to the perception on whether the process of learning happens during the test, the findings are also indicated in Table 1. The majority of the students (slightly above $87 \%$ ) agreed that the process of learning takes place during the test. The perception after the implementation for the second time is even more positive since 97.2 percent students admitted that they learned while doing the test. This finding implies to a certain extent that they experience the process of learning during the test.

Table 2 shows the students' answers regarding the extent to which they agreed with and considered that they eventually liked or disliked the idea of the new design and the extent to which they would keep the design for future quiz.

Table 2 Preference and Perpetuation of the Design

\begin{tabular}{|c|c|c|c|c|c|c|c|c|}
\hline & \multicolumn{4}{|c|}{$\begin{array}{c}\text { Preference } \\
\text { (the New Design vs Conventional Testing) }\end{array}$} & \multicolumn{4}{|c|}{$\begin{array}{c}\text { New Design } \\
\text { to Continue or Not }\end{array}$} \\
\hline & $\begin{array}{c}\text { First } \\
\text { Percept- }\end{array}$ & $\begin{array}{l}\text { Second } \\
\text { Percept- }\end{array}$ & \multicolumn{2}{|c|}{ Average } & $\begin{array}{c}\text { First } \\
\text { Percept- }\end{array}$ & $\begin{array}{l}\text { Second } \\
\text { Percept- }\end{array}$ & \multicolumn{2}{|c|}{ Average } \\
\hline$A$ & $\begin{array}{c}44 \\
(80 \%)\end{array}$ & $\begin{array}{c}26 \\
(72.2 \%)\end{array}$ & $\begin{array}{c}70 \\
(76.92 \%)\end{array}$ & $76.92 \%$ & $\begin{array}{c}44 \\
(80 \%)\end{array}$ & $\begin{array}{c}22 \\
(61.1 \%)\end{array}$ & $\begin{array}{c}66 \\
(72.53 \%)\end{array}$ & $72.53 \%$ \\
\hline $\bar{B}$ & $\begin{array}{c}2 \\
(3.6 \%) \\
\end{array}$ & $\begin{array}{c}0 \\
(0 \%) \\
\end{array}$ & $\begin{array}{c}2 \\
(2.2 \%) \\
\end{array}$ & \multirow{2}{*}{$23.08 \%$} & $\begin{array}{c}5 \\
(9.1 \%) \\
\end{array}$ & $\begin{array}{c}3 \\
(8.3 \%) \\
\end{array}$ & $\begin{array}{c}8 \\
(8.79 \%) \\
\end{array}$ & \multirow{2}{*}{$27.47 \%$} \\
\hline$C$ & $\begin{array}{c}9 \\
(16.4 \%)\end{array}$ & $\begin{array}{c}10 \\
(27.8 \%)\end{array}$ & $\begin{array}{c}19 \\
(20.88 \%)\end{array}$ & & $\begin{array}{c}6 \\
(10.9 \%)\end{array}$ & $\begin{array}{c}11 \\
(30.6 \%)\end{array}$ & $\begin{array}{c}17 \\
(18.68 \%)\end{array}$ & \\
\hline Total & $\begin{array}{c}55 \\
(100 \%)\end{array}$ & $\begin{array}{c}36 \\
(100 \%)\end{array}$ & $\begin{array}{c}91 \\
(100 \%)\end{array}$ & $100 \%$ & $\begin{array}{c}55 \\
(100 \%\end{array}$ & $\begin{array}{c}36 \\
(100 \%)\end{array}$ & $\begin{array}{c}91 \\
(100 \%)\end{array}$ & $100 \%$ \\
\hline
\end{tabular}

Note: A: New design of structured group-oriented formative test; B: Individual formative test with average score taken; $\mathrm{C}$ : Individual formative test without average score taken

Source: Tamah 2020 
The figures reported in Table 2 confirm that the individual-oriented test was much more disliked than the structured group-oriented test. Slightly above 23 percent students liked the individual formative test. A similar finding was obtained when the students were asked to show their support to the implementation of the design. On the first data collection, after Quiz 1, they were asked which type of formative test to conduct for Quiz 2. They were fundamentally asked to opt for a structured group-oriented or an individual-oriented test. Their answers are seen in Table 2.

On the second data collection, after Quiz 2, they were asked which type of formative test to conduct for their juniors later when the course was held in the following academic year. Their answers were seen in Table 2 (second perception). Clearly seen in Table 2 above is that the majority $(72.53 \%$ of students) would like the teacher to continue it. They argued for the new design to be maintained. When the item asking them to confirm if they had ever experienced the implementation of the new design in other classes, it is found that no students admitted they had. The innovation is, therefore, confirmed 100 percent, at least in this case study.

\section{Reflections and Future Directions}

The researcher must admit that this innovation is, in fact, her response to a call to be an agent of change for the sake of our education - one indication of professional development. Based on the literature review presented, this study may be regarded as one of the pioneering studies revealing a new assessment design. The students' voice presented above has revealed the inventiveness of the three-argument assessment design with regard to assessment-oriented formative test. The design is also perceived positively as the majority of the students (above $90 \%$ ) came to an understanding on the two disputes: that the teacher had implemented the correct way to assess group work and that the teacher had made the students learn (see Table 1), and therefore the majority, more than three-quarters, like the implementation (see Table 2).

From Table 2 (contrasting options [A] and [B and $\mathrm{C}]$ ) it is evident that the majority of the students liked the new design (structured group-oriented test; option [A]) more than the individual or conventional oriented test (options [B] and [C]). However, their preference toward the new design decreases slightly (about 8\%) from 80 percent to 72.2 percent. This finding indicates that after the students experience the model twice, they become less positive toward the new design. This surprising finding needs further investigation.

Likewise, from Table 2 (contrasting options [A] and [B and C]) it is evident that the majority of the students wanted the structured group-oriented test (option [A] to be maintained). However, their support towards the new insights decreased slightly (about 19\%) from 80 percent to 61.1 percent. This finding indicates that after the students experienced the model twice, they became less positive in supporting the new insights. These particular findings are worth investigating. Hopefully, more teachers are involved in implementing it in other classroom contexts for this identified challenge so that more conclusive findings can be claimed. Improvement on the innovative practices is inevitable.

\section{Conslusion}

It is worth noting here that although the findings of this study contribute to a certain extent to the attempt to make formative testing more genuine, as shown in the positive response obtained, a few limitations ought to be indicated. First, this study spanned only one semester. A more longitudinal study could have produced more illustrative results. Second, the study findings are based on a single group of students from one institution. Third, this study does not make use of interviews to provide the writer with the chance of exploring the opinions thoroughly. Future replication study can then employ the use of interviews to result in a much more inclusive conclusion. 
This innovation triggers the need for further inquiries about what can further be evaluated from the process-oriented test administration. Besides, rubrics are worth researching to measure how the positive interdependence and individual accountability are practiced by pairs during the test. Tamah (2011) has previously found that three patterns emerged when students of different levels of ability ask for assistance and get assisted in their interaction while working during non-test atmosphere. Other researchers might want to examine the interaction while the paired students are on test atmosphere. In other words, future studies can be attempted to see what pattern of dialogic interaction happens during the test which is less threatening than the individual test.

\section{Acknowledgement}

The writer is grateful to the support of the Head of the English Department and the Dean of the Teacher Training Faculty of Widya Mandala Surabaya Catholic University. Willy Renandya also deserves her thankfulness for his encouragement to publish this manuscript. The writer is also indebted to Martin Hayden, a full-time lecturer at School of Education, Southern Cross University, Lismore, Australia. He has spent his valuable time on assisting with the language clarity. The writer discloses receipt of the financial support for the research, authorship, and/or publication of this article from the Research Institute of Widya Mandala Surabaya Catholic University, Indonesia, and the Directorate of Research and Community Service, Indonesia Ministry of Research, Technology and Higher Education. Last but not least, the writer is grateful to the two reviewers involved in the blind review process. The valuable feedback provided has brought about more refined content so that this article can be more understandable for a wider international research community.

\section{REFERENCES}

Bangert-Drowns, Robert L., James A. Kulik, and Chen-Lin C. Kulik. 1991. "Effects of Frequent Classroom Testing." Journal of Educational Research 85 (2): 89-99. https://www.gwern.net/docs/spacedrepetition/1991-bangert-drowns.pdf.

Brown, H. Douglas, and Priyanvada Abeywickrama. 2010. Language Assessment: Principles and Classroom Practices, 2nd Edition. New York: Pearson Education, Inc.

Brown, James Dean. 2016. “Assessment in ELT: Theoretical Options and Sound Pedagogical Choices.” In English Language Teaching Today: Linking Theory and Practice, edited by Willy A. Renandya and Handoyo Puji Widodo, 67-82. Dordrecht: Springer International Publishing.

Center for Educational Research and Innovation. n.d. Assessment for Learning: Formative Assessment. Accessed February 22, 2018. https://www.oecd.org/site /educeri21st/40600533.pdf.

Guskey, Thomas R. 2000. Evaluating Professional Development. Thousand Oaks, CA: Corwin Press.

Hughes, Arthur. 1989. Testing for Language Teachers. Cambridge: Cambridge University Press.

Jacobs, George M., and Willy A. Renandya. 2016. "Student-Centred Learning in ELT." In English Language Teaching Today: Linking Theory and Practice, edited by Willy A. Renandya and Handoyo Puji Widodo, 13-23. Dordrecht: Springer International Publishing.

Lantolf, James P., ed. 2000. Sociocultural Theory and Second Language Learning. Oxford: Oxford University Press.

McDaniel, Mark A., Kathleen M. Widman, and Janis L. Anderson. 2012. "Using Quizzes to Enhance Summative-Assessment Performance in a Web-Based Class: An Experimental Study." Journal of Applied Research in Memory and Cognition 1 (1): 18-26. https://psycnet.apa.org/doi/10.1016/j.jarmac.2011.10.001. 
McKeachie, Wilbert J. 1994. Teaching Tips: Strategies, Research, and Theory for College and University Teachers. Lexington: D.C. Heath and Company.

Mercer, Neil. [1995] 2000. The Guided Construction of Knowledge: Talk Amongst Teachers and Learners. Clevedon: Multilingual Matters Ltd.

Moyosore, Olagunju Asimiyu. 2015. "The Effect of Formative Assessment on Students' Achievement in Secondary School Mathematics." International Journal of Education and Research 3 (10): 481-490. https://www.ijern.com/journal/2015/October2015/37.pdf.

Tamah, Siti Mina. 2011. "Student Interaction in the Implementation of the Jigsaw Technique in Language Teaching." PhD. diss. University of Groningen. https://www.rug.nl/research/portal/files/2541505/thesis.pdf.

2017. Pernak-pernik Kerja Kelompok Berbasis Pembelajaraan Kooperatif [The Nuts and Bolts of Cooperative Learning Oriented Group Work]. Surabaya: Unika Widya Mandala. http://repository.wima.ac.id/12440.

Tamah, Siti Mina, and Luluk Prijambodo. 2014. Metode Asesmen Berbasis Pembelajaran Kooperatif [Methods of Cooperative Learning-Based Assessment]. Research Report. Unika Widya Mandala, Surabaya, Indonesia. http://repository.wima.ac.id/4496.

Tamah, Siti Mina, and Luluk Prijambodo. 2015. Model Asesmen Pembelajaran Kooperatif: Strategi Menjawab Tantangan [Models of Cooperative Learning Assessment: Strategies to Respond to Challenges]. Surabaya: Revka Petra Media. http://repository.wima.ac.id/4138.

Tamah, Siti Mina, and J. V. Djoko Wirjawan. 2018. Kerja kelompok Ber-struktur ${ }^{++}$: Pelaksanaan dan Asesmennya [Structured++ Group Work: Its Implementation and Assessment]. Research Report. Widya Mandala Catholic University Surabaya, Indonesia. http://repository.wima.ac.id/16634.

Tamah, Siti Mina, and J. V. Djoko Wirjawan. 2019. "Assessment-Oriented Formative Test." International Journal of Innovation and Learning. 26 (1): 66-81. https://doi.org/10.1504/IJIL.2019.10021091.

Torrance, Harry, and John Pryor. 1998. Investigating Formative Assessment: Teaching, Learning and Assessment in the Classroom. Maidenhead: Open University Press.

Wambuguh, Oscar, and Theo Yonn-Brown. 2013. "Regular Lecture Quizzes Scores as Predictors of Final Examination Performance: A Test of Hypothesis Using Logistic Regression Analysis." International Journal for the Scholarship of Teaching and Learning 7 (1): Article 7. https://digitalcommons.georgiasouthern.edu/ij-sotl/vol7/iss1/7.

Warsono, and Hariyanto. 2012. Pembelajaran Aktif: Teori dan Asesmen [Active Learning: Theory and Assessment]. Bandung: PT Remaja Rosdakarya Offset.

Wenger, Etienne. 1998. Communities of Practice: Learning, Meaning, and Identity. New York: Cambridge University Press. https://doi.org/10.1017/CBO9780511803932.

Wiliam, Dylan, Clare Lee, Christine Harrison, and Paul Black. 2004. "Teachers Developing Assessment for Learning: Impact on Student Achievement." Assessment in Education: Principles, Policy \& Practice $11 \quad$ (1): $49-65$. https://doi.org/10.1080/0969594042000208994.

Xethakis. 2016. "Creating Conditions for Collaborative Learning in the Language Classroom." PanSIG Journal 351-357.

\section{ABOUT THE AUTHOR}

Siti Mina Tamah: Full-time Lecturer, English Department of Teacher Training Faculty of Widya Mandala Surabaya Catholic University, East Java, Indonesia 
The International Journal of Interdisciplinary

Educational Studies is one of six thematically focused

journals that support the Interdisciplinary Social

Sciences Research Network. The Research Network is

comprised of a journal collection, book imprint,

conference, and online community.

The journal presents studies that exemplify the disciplinary and interdisciplinary practices of the social sciences. As well as articles of a traditional scholarly type, this journal invites case studies that take the form of presentations of practice-including documentation of socially engaged practices and exegeses analyzing the effects of those practices.

The International Journal of Interdisciplinary

Educational Studies is a peer-reviewed, scholarly journal. 